\title{
About the Upcoming Issues
}

I continue to receive an increasing number of unsolicited papers for publication in the Journal of Vocational Rehabilitation. Some of those may fit into future themes already established. If possible, we will try and work them in. If not, I will return them as soon as possible.

Over the next year, I will be looking for two to four new themes to develop issues around. We do have the following well underway and they will have exciting content:

Topic

- Visual Impairment and Multiple Handicaps

- Career Development and Training

- Community Integration

- Parent and Family Involvement

- Personnel Preparation and Training

\section{Guest Editor}

Steve Lyon, Ph.D.

University of Pittsburgh

Adelle Renzaglia, Ph.D.

University of Illinois

Al Condeluci, Ph.D.

United Cerebral Palsy,

Pittsburgh

Rud Turnbull and Ann Turnbull

University of Kansas

Martha Walker, Ph.D.

Kent State University

Susan Brody-Hasazi, Ph.D.

University of Vermont

Let me know if you are interested in developing an issue. 